Trinity College

Trinity College Digital Repository

Faculty Scholarship

2007

Environmental Correlates of Nesting Success in Red-Shouldered

Hawks

Joan L. Morrison

Trinity College, joan.morrison@trincoll.edu

Michael McMillian

Jonathan B. Cohen

Virginia Polytechnic Institute and State University

Daniel H. Catlin

Virginia Polytechnic Institute and State University

Follow this and additional works at: https://digitalrepository.trincoll.edu/facpub

Part of the Biology Commons 


\title{
ENVIRONMENTAL CORRELATES OF NESTING SUCCESS IN RED-SHOULDERED HAWKS
}

\author{
JoAn L. Morrison ${ }^{1,3}$, Michael MCMillian ${ }^{1,4}$, JONATHAN B. COHEN ${ }^{2}$, AND \\ DANIEL H. CATLIN ${ }^{2}$ \\ ${ }^{\prime}$ MacArthur Agro-Ecology Research Center, 300 Buck Island Ranch Road, Lake Placid, Florida 33852 \\ ${ }^{2}$ Department of Fisheries and Wildlife Science, Virginia Tech, 100 Cheatham Hall, Blacksburg, VA 24061
}

Abstract. We evaluated the influence of weather on reproduction of the Red-shouldered Hawk (Buteo lineatus) in an agricultural landscape in south-central Florida where we found relatively high densities of successfully nesting hawks. We used a generalized linear modeling approach within an information-theoretic framework to examine the influence of total rainfall, rainfall frequency, and temperature on the timing of nesting, nesting success, and productivity of hawks during 1995-2000. The best models indicated an influence of rainfall frequency and laying period on hawk reproduction. During years with less frequent rainfall in the summer and fall months prior to the beginning of the breeding season, fewer pairs attempted to nest, and hawks nested later and had smaller clutch sizes and lower productivity. Hawks that nested later in the breeding season had lower hatching success and lower overall nest success. Although Red-shouldered Hawks are generally reported to inhabit forested landscapes throughout their range, a common feature seems to be a dependence on wetlands and riparian habitat for foraging. We propose that the proportion of wetlands throughout the landscape is a unique aspect of south-central Florida that may allow for persistence of unusually high numbers of hawks.

Key words: agriculture, Florida, nest success, productivity, rainfall, raptor, Redshouldered Hawk.

\section{Correlatos Ambientales del Éxito de Nidificación en Buteo lineatus}

Resumen. Evaluamos la influencia del clima en la reproducción de Buteo lineatus en un paisaje agrícola en el centro-sur de Florida, donde encontramos densidades relativamente altas de aguiluchos de esta especie nidificando exitosamente. Empleamos un enfoque estadístico de modelos lineales generalizados dentro del marco de la teoría de la información para examinar la influencia de la precipitación total, la frecuencia de precipitación y la temperatura en las fechas de nidificación sobre el éxito de nidificación y la productividad de los aguiluchos entre 1995 y 2000. Los mejores modelos indicaron una influencia de la frecuencia de la precipitación y del período de puesta sobre la reproducción de los aguiluchos. Durante los años con precipitaciones menos frecuentes durante el verano y los meses de otoño anteriores al comienzo de la estación de cría, un menor número de parejas intentaron nidificar, y éstas nidificaron más tarde y tuvieron tamaños de nidada menores con una menor productividad. Los aguiluchos que nidificaron más tarde en la estación reproductiva presentaron un éxito de eclosión menor y un éxito general de nidificación menor. A pesar de que generalmente se informa que $B$. lineatus habita paisajes boscosos a lo largo de su rango de distribución, una característica común parece ser la dependencia de los humedales y ambientes ribereños para forrajear. Proponemos que la alta proporción de humedales a lo largo del paisaje es una característica única del centro-sur de Florida, lo que podría permitir la persistencia de densidades inusualmente altas de aguiluchos.

\section{INTRODUCTION}

The breeding season of birds generally occurs when conditions are most favorable for re-

Manuscript received 22 November 2005; accepted 26 April 2007.

${ }^{3}$ Present address: Department of Biology, Trinity College, 300 Summit St., Hartford, CT 06106. E-mail: joan.morrison@trincoll.edu

${ }^{4}$ Present address: Florida Fish and Wildlife Conservation Commission, Lake Wales, FL 33859. production (Lack 1968), and weather has been well documented as an important factor influencing the reproductive biology of many species. A number of studies have shown that rainfall provides a stimulus to breeding and that variability in precipitation, both directly and indirectly as it affects hydrology, may influence nesting density, reproductive effort, and nesting success of birds in both temperate and arid regions (Bildstein et al. 1990, Zann et al. 1995, Lloyd 1999). 
Annual variation in rainfall may influence reproductive parameters indirectly through effects on food availability. For example, the timing of breeding and reproductive success of wading birds nesting in freshwater wetlands is highly dependent on present and past surface water conditions, as they influence the distribution and availability of prey (Ogden et al 1980, Frederick and Collopy 1989, Cézilly et al 1995). Rainfall may affect foraging success of predators by altering visibility (Grubb 1977) or behavior (Stinson 1980) of prey. The influence of rainfall may occur through interactions with predator-mediated processes, density-dependence, or nest type and location (Bennetts et al. 2000, Morrison and Bolger 2002, Radford and Du Plessis 2003, Fletcher and Koford 2004). Interactions among environmental variables, for example precipitation and temperature, may affect the number of pairs breeding (Hafner et al. 1994), a species' primary prey (Gargett et al. 1995, Steenhoff et al. 1997), hunting effort (Rijnsdorp et al. 1981), or provisioning rates (Redpath et al. 2002), although responses may differ among coexisting species (Kostrzewa and Kostrzewa 1990, 1991).

The Red-shouldered Hawk (Buteo lineatus) occupies woodlands throughout much of North America. Studies of the species' breeding biology across its range have described its nesting habitat as mature riparian or bottomland hardwood forests, although hawks also nest in upland forests and in woodlots in suburban areas. Nests typically are found in large mature trees, and hawks forage in open areas, marshes, and wetlands (Moorman et al. 1999, McLeod et al. 2000, Dykstra et al. 2003), generally feeding on small mammals and herpetofauna (Crocoll 1994).

We studied the reproductive biology and success of Red-shouldered Hawks in southcentral Florida where, although the species has been reported as common (Nicholson 1930, Bohall and Collopy 1984), little information is available. In the south-central peninsula, we recorded Red-shouldered Hawks occupying habitat very different from that reported elsewhere as typical for the species (Bloom et al. 1993, Moorman and Chapman 1996). Interactions among environmental factors within different habitats may have a large influence on reproductive biology. Our main objectives were to evaluate nesting success and identify environmental factors potentially influencing the reproductive biology of this hawk in a part of its range where it has been little studied and habitat occupancy may be unusual.

\section{METHODS}

\section{STUDY AREA}

We studied Red-shouldered Hawks from 1995 to 2000 at the MacArthur Agro-Ecology Research Center (MAERC), an approximately 4170 ha working cattle ranch located in Highlands County, in the south-central peninsula of Florida $\left(27^{\circ} 09^{\prime} \mathrm{N}, 81^{\circ} 11^{\prime} \mathrm{W}\right)$. Formerly wet prairie, the landscape in this region currently is characterized by large open expanses of grasslands, typically pasture and prairie, dotted with numerous shallow ponds, wetlands, marshes, and scattered or small clumps of live oaks (Quercus virginiana), cabbage palms ( $\mathrm{Sa}$ bal palmetto), pine (Pinus spp.), and cypress (Taxodium spp.).

The landscape at MAERC is typical of the region. In the 1960s, extensive ditches were dug to improve drainage. Numerous ditches of varying depths and hydroperiod crisscross the site and during the rainy season connect over 500 seasonally flooded wetlands and marshes ranging in size from a few square meters to 90 ha. The primary land use at MAERC is cattle ranching, although citrus production occurred on an 80 acre grove at the site during our study. Wooded areas averaging $1.3 \pm$ 0.3 ha (range: $<0.01-77.5$ ha, $n=389$ ) cover about $6 \%$ of the total area.

Southern Florida has a humid, subtropical climate with a distinct annual cycle of temperature and precipitation (Chen and Gerber 1990). During the rainy season (June through September) temperatures are warm and relatively uniform, averaging about $28^{\circ} \mathrm{C}$. Convective rains and thunderstorms occur almost daily. During October through December rainfall typically declines dramatically in both total amount and frequency, and temperatures are cooler but rarely drop below freezing.

\section{NEST SEARCHING AND MONITORING}

We searched for nests beginning in December each year by observing the behavior of hawks and investigating individual trees across the entire study area; thus, we are confident that all active nests on MAERC were found during each year of the study. Some pairs built nest 
structures each year that were not used, thus we defined an active nest as one in which eggs were laid. We monitored breeding chronology and determined nest contents every 1-2 weeks using a mirror attached to a telescoping fiberglass pole. We divided each month during which we found active nests into two laying periods: the first (days 1-15) or second (days 16-end) half of each month. We assigned initiation of each nest to one of these laying periods based on either the known time of egg-laying or by extrapolation from known hatching or fledging dates, assuming 33 and 45 days for length of the incubation and nestling periods, respectively (Crocoll 1994). If a nest failed during incubation and we were unable to assign a laying period, we did not include it in analyses of breeding chronology for that year.

\section{REPRODUCTIVE PERFORMANCE}

We defined reproductive success as the probability of a nesting attempt resulting in at least one young surviving to fledging as calculated using the Mayfield method (Mayfield 1961, Johnson 1979). To assess differences in breeding chronology among years, we first ranked all nests in ascending order according to the nesting period in which the clutch was laid. We then divided the entire set of rankings into quartiles to determine the percentage rank for each nest. Based on the quartiles, we considered early-season nests to be those in which eggs were laid before 16 February and late-season nests those in which eggs were laid after 15 March. We used program CONTRAST to compare Mayfield nest success probabilities between early and late nests (Sauer and Williams 1989).

\section{RAINFALL AND REPRODUCTION}

We determined that the hawks in our study area nested primarily between January and April; therefore, we considered the hawks' biological year to be May through April. Using precipitation and temperature data collected daily at MAERC and at two closely adjacent (within $5 \mathrm{~km}$ ) stations (National Oceanic and Atmospheric Administration 2007, South Florida Water Management District 2007), we developed environmental variables to be used in our assessment of possible factors influencing the breeding biology of Red-shouldered Hawks. Rainfall data from all stations were summed then averaged to represent total monthly rainfall for the local area in which MAERC is situated. We also determined the percent deviation of total monthly rainfall from monthly averages calculated for the 20 -year period of 1980-2000 (National Oceanic and Atmospheric Administration 2007) for each month of the study period. We classified each year of the study as wet or dry if total breeding year rainfall was $\geq 2$ times the standard error (approximately 10\%) either above or below the 20-year average for May-April, respectively. Because the frequency of rainfall may be as important as total amount received (Gende et al. 1997, Redpath et al. 2002), we also calculated the average percentage of days each month that the local area received essentially no $(\leq 0.25 \mathrm{~cm}$ total) rainfall. Similarly, we determined average maximum and minimum temperatures for each month of the study period and used the percent deviation of these values from the respective 20-year averages as indices of extreme heat or cold.

We developed these rainfall and temperature variables for the Red-shouldered Hawk's biological year (May-April), for the breeding season (January-April), and for all combinations of months we considered relevant to the hawk's reproduction-for example, the wet season (June-September), onset of the dry season (October-November), two months prior to onset of breeding (November-December), three months prior to breeding (OctoberDecember), early breeding season (JanuaryFebruary)-for six breeding seasons, 1995 through 2000. For each breeding season, we determined the number of pairs that attempted to nest, and for each nest we recorded laying period, clutch size, hatching success (number of eggs laid per nest that hatched), Mayfield probability of nest success, and productivity (number of fledglings per nest attempt).

\section{STATISTICAL ANALYSES}

We analyzed the data within a generalized linear modeling framework using a repeated measures model (PROC MIXED in SAS version 9.1.3; SAS Institute 2003), with year as the subject, laying period, hatching success, and productivity as the dependent variables, and all combinations of weather variables for the monthly periods noted above as explanatory variables. To evaluate influences on nest 
TABLE 1. Reproductive parameters for Red-shouldered Hawks in south-central Florida, 1995-2000. Early nests are those initiated before 16 February and late nests are those initiated after 15 March. Results are presented as mean $\pm \mathrm{SE}$ except where noted.

\begin{tabular}{lcccccc}
\hline \multicolumn{1}{c}{ Parameter } & 1995 & 1996 & 1997 & 1998 & 1999 & 2000 \\
\hline Nest attempts & 33 & 41 & 25 & 45 & 45 & 20 \\
Median laying period & $1-15 \mathrm{Mar}$ & $16-29 \mathrm{Feb}$ & $1-15 \mathrm{Mar}$ & $16-28 \mathrm{Feb}$ & $1-15 \mathrm{Mar}$ & $1-15 \mathrm{Mar}$ \\
Early nests & $4(12 \%)$ & $10(24 \%)$ & $2(8 \%)$ & $5(11 \%)$ & $9(20 \%)$ & $0(0 \%)$ \\
Late nests & $2(6 \%)$ & $4(10 \%)$ & $11(44 \%)$ & $3(7 \%)$ & $7(16 \%)$ & $5(25 \%)$ \\
Clutch size & $1.97 \pm 0.07$ & $2.22 \pm 0.11$ & $1.68 \pm 0.10$ & $1.91 \pm 0.05$ & $1.89 \pm 0.06$ & $1.70 \pm 0.11$ \\
Hatching success & 1.00 & 0.79 & 0.60 & 0.94 & 0.59 & 0.76 \\
Mayfield nest success probabilities (Mean $\pm \mathrm{SD})^{\mathrm{a}}$ & & & & & \\
$\quad \begin{array}{l}\text { Incubation period } \\
\text { Nestling period }\end{array}$ & $0.93 \pm 0.04$ & $0.62 \pm 0.00$ & $0.34 \pm 0.00$ & $0.78 \pm 0.00$ & $0.48 \pm 0.00$ & $0.69 \pm 0.00$ \\
$\quad$ Overall & $0.94 \pm 0.02$ & $0.80 \pm 0.00$ & $0.55 \pm 0.00$ & $0.92 \pm 0.00$ & $0.93 \pm 0.00$ & $0.88 \pm 0.00$ \\
Number fledged per nesting & $0.92 \pm 0.00$ & $0.66 \pm 0.00$ & $0.29 \pm 0.00$ & $0.82 \pm 0.00$ & $0.53 \pm 0.00$ & $0.70 \pm 0.00$ \\
$\quad$ attempt & $1.76 \pm 0.12$ & $1.27 \pm 0.14$ & $0.48 \pm 0.14$ & $1.64 \pm 0.11$ & $0.98 \pm 0.12$ & $0.90 \pm 0.12$ \\
Nest failures (\% of all nest & $2(6)$ & $11(27)$ & $16(64)$ & $6(13)$ & $15(33)$ & $4(20)$ \\
$\quad$ attempts) & & & & & & 0.90 \\
\hline
\end{tabular}

a Where SD is shown as $0.00, \mathrm{SD}<0.01$.

success, we used a repeated measures logistic regression model (PROC NLMIXED in SAS). When modeling hatching success, nesting success, and productivity, we also used laying period as an explanatory variable. Because many of the explanatory variables were correlated, each model evaluated for a particular reproductive parameter contained only one explanatory variable, resulting in evaluation of over 80 models for each parameter. Model selection was based on Akaike's information criterion corrected for small sample sizes $\left(\mathrm{AIC}_{c}\right.$; Akaike 1973, Burnham and Anderson 1998).

We used simple correlation to examine the potential influence of environmental variables on the number of nesting pairs each year and on clutch size because of low variability in this parameter among all nests in all years. To assess potential density-dependent effects on reproduction, we examined correlations between the number of nesting pairs and clutch size, nest success, and productivity for each year. Statistical analyses were conducted using SAS (SAS Institute 2003) and SYSTAT version 8.0 (SPSS 1996). Results are reported as mean \pm SE unless otherwise indicated.

\section{RESULTS}

\section{BREEDING CHRONOLOGY AND NESTING BIOLOGY}

From 1995 to 2000 , in the sparsely wooded agricultural landscape at MAERC, we located 209 active Red-shouldered Hawk nests. All nesting hawks found were in adult plumage. We found nests in single trees and in the largest hammocks on MAERC; some of the larger hammocks contained more than one nesting pair of hawks during the same breeding season. Nearest neighbor distances between hawk nests averaged $542 \pm 230 \mathrm{~m}$ (range: $184-1123 \mathrm{~m}$ ).

Because many individuals were banded, we know that the number of pairs at the site was similar among years $(\sim 50$, representing approximately 1.1 pairs per $100 \mathrm{ha}$ ). However, the number of pairs that attempted to nest each year varied widely (Table 1). In most years, nests were initiated between January and April, although the median egg-laying period varied among years (Kruskal-Wallis test, $H_{5}=41.6, P$ $<0.01)$. Most egg-laying occurred in the second half of February during 1996 and 1998, and higher proportions of nests were initiated late in the season (after 15 March) during 1997, 1999, and 2000 (Table 1, Fig. 1). Average clutch size was $1.9 \pm 0.1$ eggs and differed among years $\left(F_{5}\right.$ $=5.1, P<0.01)$. Modal clutch size was two for all years (77\% of all nests), although higher proportions of one-egg clutches were observed in 1997 and 2000, and no three-egg clutches were observed in those years (Fig. 2). Overall Mayfield nest success varied among years (Table 1), but early-nesting pairs generally had a higher probability of nesting success (mean \pm $\mathrm{SD}=0.66 \pm<0.01, n=52$ ) than late-nesting pairs (mean $\pm \mathrm{SD}=0.41 \pm<0.01, n=30, \chi^{2}{ }_{1}$ $=312.5, P<0.01)$. 


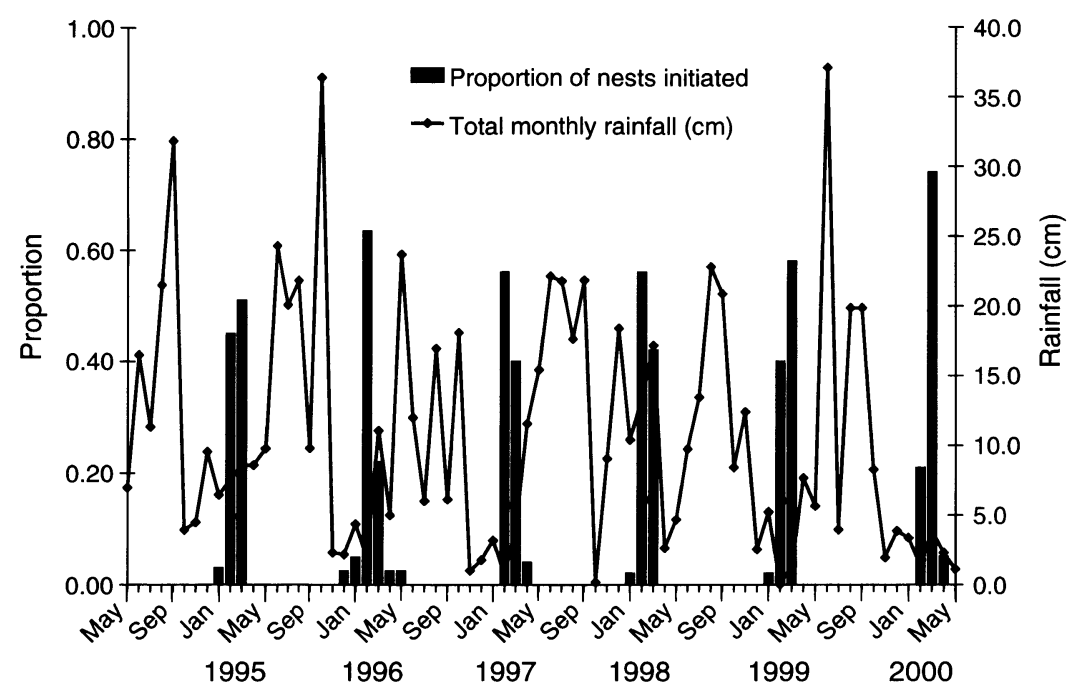

FIGURE 1. During 1995-2000, most pairs of Red-shouldered Hawks at the MacArthur Agro-Ecology Research Center in south-central Florida laid eggs during the dry season, January through April, following the rainy summer season.

\section{RAINFALL AND REPRODUCTION}

The best models indicated an influence of rainfall frequency and laying period on Redshouldered Hawk reproduction (Table 2). Hawks nested later and had lower productivity in years with lower rainfall frequency (more norain days) during the summer and fall months prior to the beginning of the breeding season (Table 3). Hawks that nested later in the breeding season had lower hatching success

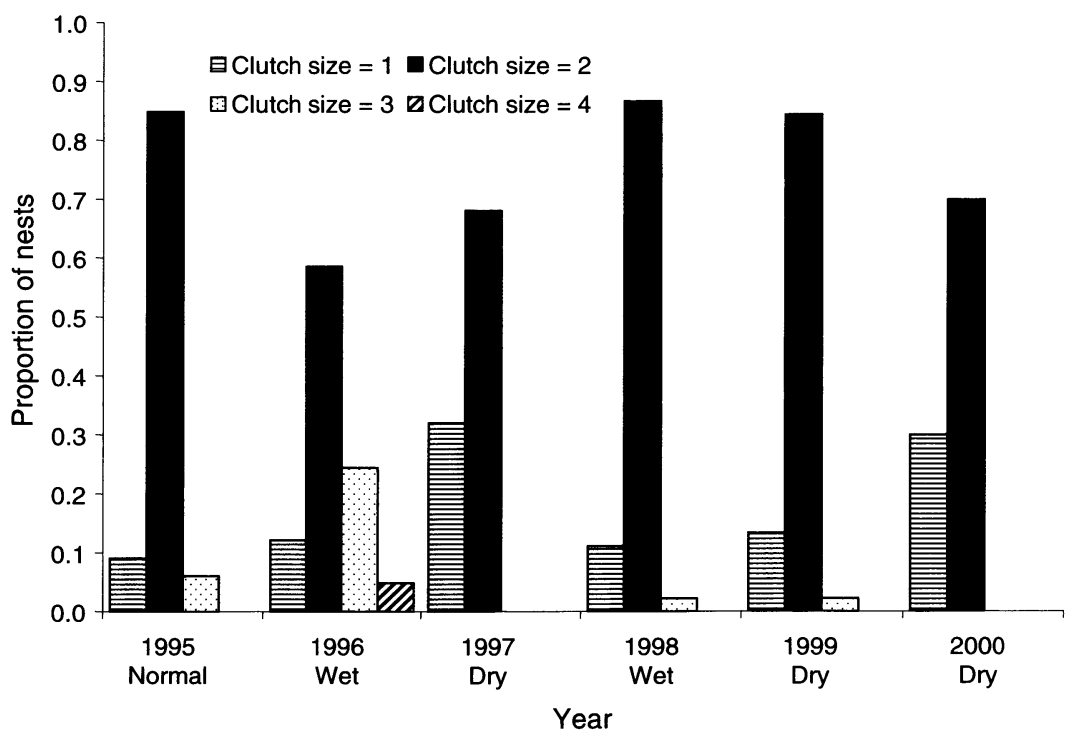

FIGURE 2. Most pairs of Red-shouldered Hawks at the MacArthur Agro-Ecology Research Center in south-central Florida laid two-egg clutches each year, in 1995-2000. Clutches of three or four eggs were recorded primarily during normal to wet years, and higher proportions of one-egg clutches were seen in dry years $(n=209$ known clutches). Wet or dry is defined as $\geq 2$ times the standard error (approximately $10 \%$ ) either above or below the 20-year average total May-April rainfall at the site. 
TABLE 2. Selection results for models explaining variation in reproductive parameters of Red-shouldered Hawks in south-central Florida, 1995-2000. Sample size $=209$ active nests. Models were evaluated using Akaike's information criterion corrected for small sample size $\left(\mathrm{AIC}_{c}\right)$, likelihood, number of estimated parameters $(K)$, difference in $\mathrm{AIC}_{c}$ from the top model $\left(\triangle \mathrm{AIC}_{c}\right)$, and model weight $\left(w_{i}\right)$. The top three models for each reproductive parameter are presented, although the next-best models were in all cases $>4 \mathrm{AIC}_{c}$ units from the top model.

\begin{tabular}{|c|c|c|c|c|}
\hline Model & Likelihood & $K$ & $\Delta \mathrm{AIC}_{c}{ }^{\mathrm{a}}$ & $w_{i}$ \\
\hline \multicolumn{5}{|l|}{ Laying period } \\
\hline Percentage of no-rain days, Jul-Dec & 1.00 & 2 & 0.00 & 0.77 \\
\hline Percentage of no-rain days, Sep-Dec & 0.03 & 2 & 7.02 & 0.02 \\
\hline Total rainfall, Sep-Dec & 0.02 & 2 & 7.69 & 0.02 \\
\hline \multicolumn{5}{|l|}{ Hatching success } \\
\hline Laying period & 1.00 & 2 & 0.00 & 0.94 \\
\hline $\begin{array}{l}\text { Percent deviation of Jan-Feb maximum temperature from } 20 \text {-year } \\
\text { average }\end{array}$ & 0.05 & 2 & 5.92 & 0.05 \\
\hline Percent deviation of Jan maximum temperature from 20 -year average & 0.01 & 2 & 9.85 & 0.01 \\
\hline \multicolumn{5}{|l|}{ Mayfield nest success (overall) } \\
\hline Laying period & 1.00 & 2 & 0.00 & 0.61 \\
\hline Maximum Jan-Feb temperature & 0.10 & 2 & 4.69 & 0.06 \\
\hline $\begin{array}{l}\text { Percent deviation of Jan-Feb maximum temperature from } 20 \text {-year } \\
\text { average }\end{array}$ & 0.09 & 2 & 4.73 & 0.06 \\
\hline \multicolumn{5}{|l|}{ Number fledged per nesting attempt } \\
\hline Percentage of no rain days, Sep-Dec & 1.00 & 2 & 0.00 & 0.87 \\
\hline Laying period & 0.09 & 2 & 4.92 & 0.07 \\
\hline $\begin{array}{l}\text { Percent deviation of Feb maximum temperature from } 20 \text {-year } \\
\text { average }\end{array}$ & 0.02 & 2 & 7.43 & 0.02 \\
\hline
\end{tabular}

a The lowest $\mathrm{AIC}_{c}$ values were 610.83 for laying period, 454.93 for hatching success, 216.94 for nest success, and 480.81 for number fledged per nesting attempt.

and lower overall nest success. Model results also suggested a negative influence of high January-February temperatures on hatching success and nesting success, but these models received little support compared to the top models (Table 2).

The percentage of no-rain days during JulyDecember before the breeding season began was negatively associated with both the number of pairs that attempted to nest each year (Pearson product moment correlation, $\rho=$ $\left.-0.82, r^{2}=0.67, P=0.05\right)$ and clutch size $(\rho$ $\left.=-0.91, r^{2}=0.80, P=0.01\right)$. In years when it rained less often during these months, fewer hawks nested and those that did had smaller clutches. We did not detect density-dependent effects - the number of pairs that attempted to nest each year apparently did not influence clutch size, nesting success, or productivity. Productivity generally tracked the percent deviation from the 20-year average rainfall for the hawk's biological year (May-April, $\rho=0.83, r^{2}$ $=0.69, P=0.04$ ), with higher productivity during the "wet" years of 1996 and 1998 (Fig. 3).

\section{DISCUSSION}

An association between rainfall in months preceding the breeding season and reproductive success has been reported for many avian

TABLE 3. Parameter estimates for variables explaining Red-shouldered Hawk reproductive parameters, from the top model for each reproductive parameter (Table 2).

\begin{tabular}{llr}
\hline \hline \multicolumn{1}{c}{ Reproductive parameter } & \multicolumn{1}{c}{ Explanatory variable } & Estimate \pm SE \\
\hline Laying period & Percentage of no-rain days, Jul-Dec & $12.22 \pm 2.74$ \\
Hatching success & Laying period & $-0.37 \pm 0.04$ \\
Mayfield nest success (overall) & Laying period & $-0.61 \pm 1.63$ \\
Number fledged per nesting attempt & Percentage of no rain days, Sep-Dec & $-16.04 \pm 2.07$ \\
\hline
\end{tabular}




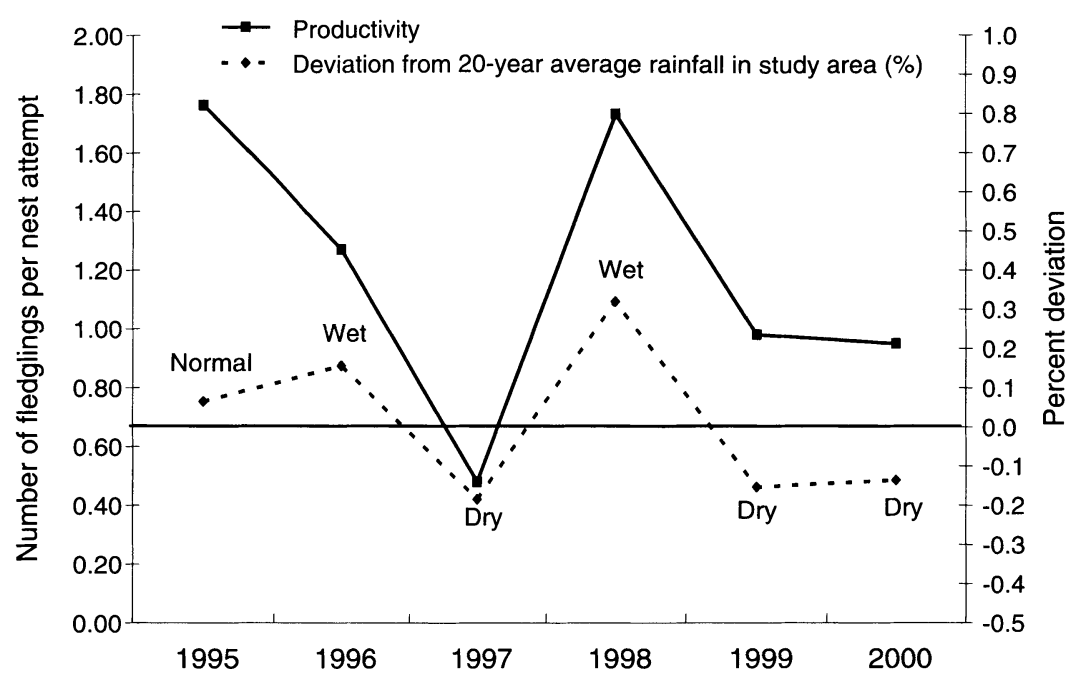

FIGURE 3. Red-shouldered Hawks nesting at the MacArthur Agro-Ecology Research Center, south-central Florida, had higher productivity during normal and wet years in 1995-2000. Wet or dry is defined as $\geq 2$ times the standard error (approximately 10\%) either above or below the 20-year average total May-April rainfall at the site.

species (Bancroft et al. 1988, Baxter 1994, Dreitz et al. 2001). Our findings suggest a similar association for the Red-shouldered Hawk in south-central Florida: rainfall during the six months prior to the start of the breeding season influenced the number of hawks nesting and the timing of egg-laying, and hawks had higher overall reproductive success during "wet" years. Similar to many other birds (Newton 1979, Verhulst and Tinbergen 1991, Morrison 1999), later-nesting hawks also had smaller clutch sizes and lower overall nest success and productivity. Given that rainfall primarily influenced the number of hawks nesting and timing of egg-laying by hawks at MAERC, laying period apparently influenced subsequent reproductive outcomes. Although our analyses provided no evidence for densitydependent effects on hawk reproduction, if rainfall during the summer and fall months preceding the breeding season each year influenced the number of breeding pairs, densitydependent effects may, in fact, have occurred, particularly during wet years.

Our results are somewhat ambiguous, however, as models indicated rainfall frequency (percentage of no-rain days), rather than total rainfall, had the greatest influence on hawk reproduction. However, for the period of 1981-
2000 we found a negative association between the percentage of no-rain days and total rainfall during July-December $\left(\rho=-0.73, r^{2}=0.54, P\right.$ $<0.01$ ); when it rained less often, total rainfall was less. Thus, our six-year study period may have been too short to gain a clear understanding of observed patterns, and a similar study conducted during different years might find associations between hawk breeding and total rainfall rather than rainfall frequency.

Our exploratory analysis of environmental factors that may influence hawk reproduction is useful for generating hypotheses about how the total amount and timing of rainfall in this region might influence the breeding biology of Red-shouldered Hawks. As for other birds in this environment, rainfall may affect abundance and availability of prey for hawks. The onset of breeding of at least 10 species of anurans coincides with rising water levels in the ditches and wetlands during the rainy season at MAERC, providing a broad prey base (Meshaka 1997, Babbitt and Tanner 2000). During drought years almost no amphibian breeding occurs at MAERC (Babbitt and Tanner 2000), perhaps resulting in fewer food resources for predators and delayed or missed breeding opportunities (Frederick and Collopy 1989). Red-shouldered Hawks regularly forage along 
the edges of ditches and wetlands at MAERC, feeding on amphibians and reptiles (over $56 \%$ of their diet; MM, unpubl. data), so variation in the number of pairs breeding and timing of egglaying could reflect variation in the amount of available foraging habitat and these important prey items. Rainfall could also affect the onset of nesting by influencing hunting effort (Rijnsdorp et al. 1981), activity of prey (Kostrzewa 1989), or capture success rates (Dawson and Bortolotti 2000, Redpath et al. 2002). If food resources are less abundant or available, breeding may be delayed if females take longer to reach breeding condition.

Our study is the first to provide informatior about the breeding biology and nest success of Red-shouldered Hawks in Florida, where they inhabit a landscape very different from that typically described for the species. We found much higher overall densities of successfully nesting hawks $(\sim 1.1$ pairs per $100 \mathrm{ha})$ relative to densities reported in other studies ( 0.09 pairs per 100 ha in Maryland [Stewart 1949]; 0.10 pairs per 100 ha in Michigan [Craighead and Craighead 1956]; 0.58 pairs per 100 ha in Neu $\rightarrow$ York [Crocoll and Parker 1989]; and 0.22 pairs per 100 ha in New Jersey [Bosakowski et al. 1992]). Throughout most of its range, the Redshouldered Hawk is reported to primarily occupy forested areas, but a common feature seems to be its dependence on wetlands and riparian zones for foraging. Perhaps the unique aspect of south-central Florida relative to other parts of this hawk's range is the proportion of wetlands throughout the landscape. In this region, the combination of an abundance of wetland habitats and distinct annual precipitation cycles may interact to support unusually high numbers of Red-shouldered Hawks.

\section{ACKNOWLEDGMENTS}

We are grateful for field assistance from B. Carlton, K. Long, J. Osgood, T. Hamer, K. Niewolny, S. McGehee, V. Dreitz, W. Jess, and J. Arnett. Thanks also to $\mathrm{P}$. Bohlen and L. Collins for providing the MAERC rainfall data. W. Meshaka, K. Babbitt, and R. Franz enlightened our thoughts about the influence of rainfall on reptiles and amphibians and hawk reproduction in the area. This manuscript benefited from the comments of $\mathrm{H}$. Swain and two anonymous reviewers. We thank the MacArthur Agro-Ecology Research Center and Archbold Biological Station, particularly G. Lollis, P. Bohlen, and G. T. Bancroft, for providing logistic support. This is contribution no. 103 from the MacArthur
Agro-Ecology Research Center of Archbold Biological Station.

\section{LITERATURE CITED}

AKAIKE, H. 1973. Information theory and an extension of the maximum likelihood principle, p. 267-281. In B. N. Petran and F. Csaki [EDS.], International symposium on information theory. 2nd ed. Akademiai Kiadi, Budapest, Hungary.

BABBITT, K. J., AND G. W. TANNER. 2000. Use of temporary wetlands by anurans in a hydrologically modified landscape. Wetlands 20:313-322.

BAncroft, G. T., J. C. Ogden, AND B. W. PAtTy. 1988. Colony formation and turnover relative to rainfall in the Corkscrew Swamp area of Florida during 1982 through 1985. Wilson Bulletin 100:50-59.

BAXTER, G. S. 1994. The influence of synchronous breeding, natal tree position and rainfall on egret nesting success. Colonial Waterbirds 17:120-129.

Bennetts, R. E., M. Fasola, H. Hafner, AND Y. KAYSER. 2000. Influence of environmental and density-dependent factors on reproduction of Little Egrets. Auk 117:634-639.

Bildstein, K. L., W. Post, J. Johnston, And P. FREDERICK. 1990. Freshwater wetlands, rainfall, and the breeding ecology of White Ibises in coastal South Carolina. Wilson Bulletin 102:84-98.

Bloom, P. H., M. D. McCrary, AND M. J. GibSon. 1993. Red-shouldered Hawk home-range and habitat use in southern California. Journal of Wildlife Management 57:258-265.

Bohall, P. G., AND M. W. Collopy. 1984. Seasonal abundance, habitat use, and perch sites of four raptor species in north-central Florida. Journal of Field Ornithology 55:181-189.

Bosakowski, T., D. G. Smith, AND R. Speiser. 1992. Status, nesting density, and macro-habitat selection of Red-shouldered Hawks in northern New Jersey. Wilson Bulletin 104:434-446.

Burnham, K. P., AND D. R. ANDERSON. 1998. Model selection and inference: a practical information-theoretic approach. Springer-Verlag, New York.

Cézilly, F., V. Boy, R. E. Green, G. J. Hirons, AND A. R. JOHNSON. 1995. Inter-annual variation in Greater Flamingo breeding success in relation to water levels. Ecology 76:20-26.

Chen, E., AND J. F. Gerber. 1990. Climate, p. 1134. In R. L. Myers and J. J. Ewel [EDS.], Ecosystems of Florida. University of Central Florida Press, Orlando, FL.

Craighead, J. J., AND F. C. Craighead JR. 1956. Hawks, owls and wildlife. Stackpole Publishing Co., Harrisburg, PA.

Crocoll, S. T. 1994. Red-shouldered Hawk (Buteo lineatus). In A. Poole and F. Gill [EDS.], The birds of North America, No. 107. The Academy of Natural Sciences, Philadelphia, PA, and The American Ornithologists' Union, Washington, DC.

Crocoll, S. T., AND J. W. Parker. 1989. The breeding biology of Broad-winged and Red- 
shouldered Hawks in western New York. Journal of Raptor Research 23:125-139.

$\rightarrow$ DAwSON, R. D., AND G. R. BORTOLOTTI. 2000. Reproductive success of American Kestrels: the role of prey abundance and weather. Condor 102:814-822.

$\rightarrow$ Dreitz, V. J., R. E. Bennetts, B. Toland, W. M. KITCHENS, AND M. W. Collopy. 2001. Spatial and temporal variability in nest success of Snail Kites in Florida: a meta-analysis. Condor 103:502-509.

DYKSTRA, C. R., J. L. HAYs, M. M. SimON, AND F. B. DANIEL. 2003. Behavior and prey of nesting Red-shouldered Hawks in southwestern Ohio. Journal of Raptor Research 37:177-187.

Fletcher, R. J., JR., AND R. R. KOFORD. 2004. Consequences of rainfall variation for breeding wetland blackbirds. Canadian Journal of Zool. ogy 82:1316-1325.

$\rightarrow$ Frederick, P. C., AND M. W. Collopy. 1989. Nesting success of five Ciconiiform species in relation to water conditions in the Florida Everglades. Auk 106:625-634.

GARGETT, V., E. GARGETT, AND D. DAMANIA. 1995. The influence of rainfall on Black Eagle breeding over 31 years in the Matobo Hills, Zimbabwe. Ostrich 66:114-121.

Gende, S. M., M. F. Willson, AND M. JacobSen. 1997. Reproductive success of Bald Eagles (Haliaeetus leucocephalus) and its association with habitat or landscape features and weather in southeast Alaska. Canadian Journal of Zoology 75:1595-1604.

GRUBB, T. G., JR. 1977. Weather-dependent foraging in Ospreys. Auk 94:146-149.

HafNer, H., Y. Kayser, AND O. Pineau. 1994. Ecological determinants of annual fluctuations in numbers of breeding Little Egrets Egretta garzetta in the Camargue, S. France. Revue Ecologie (Terre Vie) 49:53-62.

$\rightarrow$ Johnson, D. H. 1979. Estimating nest success: the Mayfield method and an alternative. Auk 96. 651-661.

Kostrzewa, A. 1989. The effect of weather on density and reproductive success in Honey Buzzards Pernis apivorus, p. 187-191. In B. U. Meyburg and R. D. Chancellor [EDS.], Raptors in the modern world. World Working Group Birds of Prey, Berlin.

Kostrzewa, A., AND R. Kostrzewa. 1990. The relationship of spring and summer weather with density and breeding performance of the Buzzard Buteo buteo, Goshawk Accipiter gentilis anc Kestrel Falco tinnunculus. Ibis 132:550-559.

Kostrzewa, R., AND A. Kostrzewa. 1991. Winter weather, spring and summer density, and subsequent breeding success of Eurasian Kestrels, Common Buzzards and Northern Goshawks. Auk 108:342-347.

LACK, D. 1968. Ecological adaptations for breeding in birds. Methuen, London.

LLOYD, P. 1999. Rainfall as a breeding stimulus and clutch size determinant in South African arid. zone birds. Ibis 141:637-643.
MAYFiELD, H. F. 1961. Nesting success calculated from exposure. Wilson Bulletin 73:255-261.

McLeod, M. A., B. A. Belleman, D. E. ANderSON, AND G. W. OEHLERT. 2000. Red-shouldered Hawk nest site selection in north-central Minnesota. Wilson Bulletin 112:203-213.

MeshaKA, W. E. 1997. The herpetofauna of Buck Island Ranch: an altered wetland in southcentral Florida. Florida Scientist 60:1-7.

MoORMAn, C. E., AND B. R. ChapMAn. 1996. Nestsite selection of Red-shouldered and Red-tailed Hawks in a managed forest. Wilson Bulletin 108:357-368.

Moorman, C. E., D. L. Howell, and B. R. ChAPMAN. 1999. Nesting ecology of Red-shouldered and Red-tailed Hawks in Georgia. Journal of Raptor Research 33:248-251.

Morrison, J. L. 1999. Breeding biology and productivity of Florida's Crested Caracaras. Condor 101:505-517.

MORRISON, S. A., AND D. T. BOLgER. 2002. Variation in a sparrow's reproductive success with rainfall: food and predator-mediated processes. Oecologia 133:315-324.

National OCEANIC AND ATMOSPheric AdminisTRATION [ONLINE]. 2007. Climate data inventories. National Climatic Data Center. <http://www. ncdc.noaa.gov/oa/climate/climateinventories. html > (15 January 2007).

NeWTON, I. 1979. Population ecology of raptors. Buteo Books, Vermillion, SD.

Nicholson, D. J. 1930. Notes from Florida. Auk 57:267.

Ogden, J. C., H. W. Kale II, and S. A. Nesbitt. 1980. The influence of annual variation in rainfall and water levels on nesting by Florida populations of wading birds. Transactions of the Linnean Society 9:115-126.

Radford, A. N., AND M. A. Du Plessis. 2003. The importance of rainfall to a cavity-nesting species. Ibis 145:692-694.

Redpath, S. M., B. E. Arroyo, B. Etheridge, F. LECKIE, K. BOUWMAN, AND S. J. THIRGOOD. 2002. Temperature and Hen Harrier productivity: from local mechanisms to geographical patterns. Ecography 25:533-540.

RiJNSDORP, A., S. DAAN, AND C. DiJkstra. 1981. Hunting in the Kestrel, Falco tinnunculus, and the adaptive significance of daily habits. Oecologia 50:391-406.

SAS INSTITUTE. 2003. SAS/STAT statistical software user's guide. Version 9.1.3. SAS Institute, Inc., Cary, NC.

Sauer, J. R., AND B. K. Williams. 1989. Generalized procedures for testing hypotheses about survival or recovery rates. Journal of Wildlife Management 53:137-142.

SOUTH FlORIDA WATER MANAGEMENT District [ONLINE]. 2007. DBHYDRO browser, environmental monitoring. <http://www.sfwmd.gov/ site/index.php?id = 38 $>$ (15 January 2007).

SPSS. 1996. SYSTAT statistical software user's guide. Version 8.0. SPSS, Inc., Chicago.

STEENHOF, K., M. N. KOCHERT, AND T. L. MCDONALD. 1997. Interactive effects of prey 
and weather on Golden Eagle reproduction $\rightarrow$ VERHULST, S., AND J. M. TINBERGEN. 1991. ExperJournal of Animal Ecology 66:350-362.

STEWART, R. E. 1949. Ecology of a nesting Redshouldered Hawk population. Wilson Bulletin 61:26-35.

$\rightarrow$ STINSON, C. H. 1980. Weather-dependent foraging success and sibling aggression in Red-tailed Hawks in central Washington. Condor 82:7680. imental evidence for a causal relationship between timing and success of reproduction in the Great Tit Parus m. major. Journal of Animal Ecology 60:269-282.

ZANN, R. A., S. R. MORTON, K. R. JONES, AND N. T. BURLEY. 1995. The timing of breeding by Zebra Finches in relation to rainfall in central Australia. Emu 95:208-222. 